\title{
Correlation between depressive symptoms and quality of life in users of psychoactive substances
}

\author{
CORRELAÇÃO ENTRE SINTOMAS DEPRESSIVOS E QUALIDADE DE VIDA DE \\ USUÁRIOS DE SUBSTÂNCIAS PSICOATIVAS
}

\section{RELACIÓN ENTRE LOS SÍNTOMAS DEPRESIVOS Y LA CALIDAD DE VIDA EN LOS USUARIOS DE SUSTANCIAS PSICOACTIVAS}

\section{Samira Reschetti Marcon'1, Jéssica Saraiva Xavier², Ariane Aguillar Barcelon², Mariano Martinez Espinosa $^{3}$, Dulce Aparecida Barbosa ${ }^{4}$}

\begin{abstract}
Objectives: To evaluate the correlation between the presence of depressive symptoms and quality of life in users of psychoactive substances from Psychosocial Attention Centers in Mato Grosso. Method: A cross-sectional analytical study, conducted in Psychosocial Attention Centers, with 109 users. The instruments used were: Medical Outcomes Study 36, Beck Depression Inventory, socio-demographic variables and the use of psychoactive substances. A Tukey analysis and a Spearman correlation were conducted with a significance level of $\alpha<0,05$. Results: The most affected domains of quality of life were emotional, social and mental health aspects, besides the strong correlation between depressive symptoms and quality of life. Conclusion: The use of psychoactive substances and the presence of symptoms significantly interfere in the life of users, which can compromise the motivation to the treatment, negatively affecting the quality of life in this population.
\end{abstract}

\section{DESCRIPTORS}

Substance-related disorders

Depression

Quality of life

Mental Health Services

Psychiatric nursing

\section{RESUMO}

Objetivos: Avaliar a correlação entre a presença de sintomas depressivos e a qualidade de vida em usuários de substâncias psicoativas dos Centros de Atenção Psicossocial de Mato Grosso. Método: Estudo transversal analítico, realizado nos Centros de Atenção Psicossocial, com 109 usuários. Foram utilizados os instrumentos Medical Outcomes Study 36, Inventário de Depressão de Beck, variáveis sociodemográficas e do uso de substâncias psicoativas. Foi realizada a análise de Tukey e correlação de Spearman com nível de significância de $\alpha<0,05$. Resultados: Os domínios mais afetados da qualidade de vida foram aspectos emocionais, sociais e de saúde mental, além de forte correlação entre sintomas depressivos e qualidade de vida. Conclusão: $O$ uso de substâncias psicoativas e a presença de sintomas interferem significativamente na vida dos usuários, o que pode comprometer a motivação para o tratamento, afetando negativamente a qualidade de vida desta população.

\section{DESCRITORES}

Transtornos relacionados ao uso de substâncias

Depressão

Qualidade de vida

Serviços de Saúde Mental

Enfermagem psiquiátrica

\section{RESUMEN}

Objetivo: Evaluar la relación de los síntomas depresivos y la calidad de vida en los usuarios de sustancias psicoactivas de los Centros de Atención Psicosocial de Mato Grosso. Método: Estudio transversal analítico realizado en los Centros de Atención Psicosocial con 109 usuarios. Se utilizaron los Instrumentos: Medical Outcomes Study 36, el Inventario de Depresión de Beck, de variables sociodemográficas y del uso de sustancias psicoactivas. Se realizó el análisis de Tukey y la correlación de Spearman con nivel de significancia de $\alpha<0,05$. Resultados: Los dominios más afectados de la calidad de vida fueron los aspectos emocionales, sociales y de salud mental, además de una fuerte correlación entre los síntomas depresivos y la calidad de vida. Conclusión: El uso de sustancias psicoactivas y la presencia de síntomas depresivos interfieren significativamente en la vida de los usuarios, lo que puede comprometer la motivación para el tratamiento, afectando negativamente la calidad de vida de esta población.

\section{DESCRIPTORES}

Trastornos relacionados con sustancias Depresión

Calidad de vida

Servicios de Salud Mental

Enfermería psiquiátrica

${ }^{1}$ Associate Professor, Nursing Faculty, Universidade Federal de Mato Grosso, Cuiabá, MT, Brazil. ${ }^{2}$ Bachelor Nursing Student, Nursing Faculty, Universidade Federal de Mato Grosso, Cuiabá, MT, Brazil. ${ }^{3}$ Associate Professor, Department of Statistics, Universidade Federal Mato Grosso, Cuiabá, MT, Brazil. ${ }^{4}$ Associate Professor, Paulista Nursing School, Universidade Federal de São Paulo, São Paulo, SP, Brazil. 


\section{INTRODUCTION}

During a long time, the abusive behavior of substances that alter the cerebral functioning causing modifications in the mental state, denominated as psychoactive substances (PAS), was treated with punitive actions for being considered a moral failure or lack of willpower ${ }^{(1)}$. However, in the last two decades, with the progressive development of scientific studies, the approach started to be done in a preventive and therapeutic way, as it was comprehended as a serious health problem, affecting diverse areas of live of an individual, with direct or indirect repercussions in the quality of life $(Q L)^{(2-4)}$.

The $Q \mathrm{~L}$ refers to the individual subjective perception of diverse aspects involving physical capacity, functional ability, emotional, social and economic aspect, intellectual function and general health state perception ${ }^{(5)}$.

Internationally and in Brazil, different instruments have been used to assess the $\mathrm{QL}$ in diverse populations. Within them, the MOS SF-36 (The Medical Outcomes Studies 36- Item Short-Form), which assess the health related QL and it was translated and validated in Brazil in $1997^{(6)}$, and the WHOQOL (World Health Organization Quality of Life) elaborated by the World Health Organization to assess the general $\mathrm{QL}^{(7)}$.

Thus, facing the proliferation of investigations about QL from the 1980s, a study conducted to describe the profile of those publications in Brazil found the fulfillment and applicability of those instruments in different populations, with older patients, chronic diseases patients, but few studies investigating PAS users were found ${ }^{(8)}$.

The use of PAS negatively interferes in QL of users affecting directly the psychological, environmental and physical self-evaluation aspects ${ }^{(2)}$. In addition, the high prevalence of psychiatric disorders in this population, confirming the chronic use of PAS as a constituting a triggering factor or as consequence of psychiatric frameworks, especially related to humor disorders and depressive $\operatorname{mood}^{(9)}$.

Although the scientific literature had discussed harms caused by the use of PAS ${ }^{(10-12)}$,studies about the use of those and QL have been conducted internationally, majorly between users of injectable drugs, opioids and/or in substitution programs (methadone), noting that the use affects $Q L$, with more losses to emotional, mental health and social functioning aspects ${ }^{(3-4,13)}$.

In Brazil, studies with this population are still scarce, especially those referred to correlate the use of PAS, $\mathrm{QL}$ and depression in general users, as well as in users during treatment in Psychosocial Attention Centers for alcohol and other drugs (CAPS-ad). This fact is reiterated by a study that investigated the scientific production about the CAPS during the period of 1998 and 2008, identifying a gap in relation to the PAS users and, within those, most of them (73.9\%) were conducted in the regions south and southeast, leaving the need of studies in other regions of Brazil(14).

Considering that chemical dependence brings innumerous losses in all life spheres of an individual(10-11), that the presence of a comorbidity, as depression, can aggravate and make it difficult the recovery process, affecting directly the quality of life and, still, that there is lack of data about the theme in the mid-west region, we believe that results can contribute to the improvement of political strategies directed to attend this population, aiming a higher adherence to treatment.

Facing the hypothesis of depressive symptoms having an important impact in the QL of SPA users, this study aims to assess the correlation between the presence of depressive symptoms and the quality of life in users of psychoactive substances in Psychosocial Attention Centers in Mato Grosso State.

\section{METHOD}

\section{Ethical Aspects}

This study was approved by the Ethics in Research Committee of the Universidade Federal de São Paulo, under the registration 0556/07 and the participant's signature of the Free and Informed Consent Term.

\section{Study design, location and period}

A cross-sectional, observational, descriptive and analytical study, developed in the Psychosocial Attention Centers for Alcohol and Other Drugs (CAPS ad) of four cities in the state of Mato Grosso: Cuiabá/capital, Várzea Grande, Rondonópolis and Barra do Garças, during the period of 2009 to 2011.

\section{Population and sample}

The population was constituted by users followed in the CAPS ad from the four cities considered. The sample was obtained by random stratified sampling of CAPS ad, proportional to the mean size of the users' population that were in treatment in the CAPS ad on the past 10 months. Thus, considering a confidence of $95 \%$, a sample error of $5 \%$, a proportion of 0.5 and an increase of $20 \%$ for losses, the sample totalized 109 users in the four CAPS ad.

It is important to note that in this population, the observed users in a set month had also the possibility of being observed in the following months. For this reason, the average number of individuals per month was used, instead of the total number in each city, as it is usual in the sampling practice.

Inclusion criteria: users with 18 years old or older using illicit PAS. 


\section{Procedures}

The data collection was after a pilot test, which showed the applicability of the instruments. The interviews were done individually, in a reserved environment, during a mean time of 40 to 50 minutes, by previously trained researchers.

Three instruments were used: 1) Questionnaire composed by socio-demographic data and regarding the use of PAS during life, nowadays, and in its first use; 2) QL by the Medical Outcomes Study 36 - Item ShortForm Health Survey ${ }^{(6)}$, a multi-dimensional instrument that assess health related QL, translated, adapted and validated in Brazil in 1997, composed by 36 items, divided in 8 scales or domains: functional capacity; physical aspects; pain; general health state; vitality; social aspects; emotional aspects and mental health. The scores varies from zero (worse health status) and 100 (best health status); 3) Beck Depression Inventory(15) (BDI), that investigates the presence of depressive symptoms. The scale is composed by 21 items, including symptoms and attitudes in four levels of intensity $(0,1,2,3)$. To define the study cut-point, in accordance with the literature, specific scores for non-diagnosed samples with affective disorders are considered, in which values smaller or equal to 15 classified the individuals as normal (without the presence of symptoms); 16 to 20 as dysphoria (sudden, transient changes of mood) and superior to 20 , suggestive of depression ${ }^{(16)}$.

\section{Statistical analysis of results}

The data processing was done with the statistical programs Statistical Package for Social Sciences (SPSS), version 15.0 and MINITAB version 15. Descriptive techniques and inferences were used. In the descriptive part, percentages, position measures and variation were used; in the inferential part, multiple analysis of variance was used. To compare the difference between the means of domains, the Tukey's test for paired comparisons and the Spearman correlation was used, with a significance level of $\alpha<0,05$, in both techniques.

\section{RESULTS}

In Table 1, it can be observed the average age of users (29.8 years), with predominance of the male gender $(84.4 \%)$, single marital status $(55.0 \%)$, and most of them had completed basic education (42.2\%), and occupation (66.1\%).

The data presented in Table 2 show the most used PAS during life: marijuana (85.3\%), base paste (77.0\%) and cocaine (70.6\%). Regarding the actual use, the base paste (31.2\%), followed by marijuana (30.3\%) and cocaine $(8.3 \%)$ were the most used. The first drug used in their lives was marijuana (74.3\%).
Table 1 - Distribution, in percentage values, of the socio-demographic characteristics of users of psychoactive substances, CAPS ad. - Mato Grosso, 2011

\begin{tabular}{llcr}
\hline $\begin{array}{l}\text { User's } \\
\text { characteristics }\end{array}$ & $(\mathbf{n}=\mathbf{1 0 9})$ & $\%$ \\
\hline Age $(\overline{\mathrm{x}} \pm D P)$ & $29.8 \pm 7.8$ & & \\
\hline Gender & Male & 92 & 84.4 \\
& Female & 17 & 15.6 \\
\hline Marital Status & Single & 60 & 55.0 \\
& Married & 38 & 34.9 \\
& Divorced & 11 & 10.1 \\
\hline Education Level & Incomplete basic education & 30 & 27.5 \\
& Complete basic education & 46 & 42.2 \\
& Complete high school & 30 & 27.5 \\
& Complete higher education & 3 & 2.8 \\
Occupation & Possess & 72 & 66.1 \\
& Do not possess & 37 & 33.9 \\
\hline
\end{tabular}

Table 2 - Distribution, in percentage number of the PAS type used during life, nowadays and in the first use among PAS users from CAPS ad. - Mato Grosso, 2011

\begin{tabular}{llcc}
\hline Psychoactive Substance & & (n =109) & \% $^{*}$ \\
\hline \multirow{4}{*}{ Use in life } & Marijuana & 93 & 85,3 \\
& Base paste & 84 & 77,0 \\
& Cocaine & 77 & 70,6 \\
& Inhalants & 32 & 29,4 \\
& Crack & 17 & 15,6 \\
& Ecstasy & 6 & 5,5 \\
Current use & LSD & 3 & 2,7 \\
\hline \multirow{3}{*}{ First use in life } & Base paste & 34 & 31,2 \\
& Marijuana & 33 & 30,3 \\
& Cocaine & 9 & 8,3 \\
\hline * The percentages do not totalize 100\% due to the fact that users reported
\end{tabular}
the use of more than one PAS in all categories.

The lower scores observed were in the emotional aspects domain and the higher in the functional capacity. To verify is the mean of the SF36 domains were statistically different, a multivariate analysis of variance (ANOVA) was used. From this analysis, it was verified the statistical difference between the scores means of the SF36 $(p<0.001)$. To verify which means were different, a multiple comparison with the Tukey method, and the different letters in the column 2, Table 3, indicate the domains as statistically different in a $5 \%$ level.

Regarding the presence of depressive symptoms it was observed that $37.6 \%$ of users, presented a suggestive cutpoint for depression and $12.8 \%$ symptoms of dysphoria.

We can observe in Table 5 a strong correlation between the BDI and the SF36 for all domains (p-values<0.05), being vitality and mental health the ones which highlights. 
Table 3 - Descriptive statistics of the SF-36 domains of PAS users, CAPS ad. - Mato Grosso, 2011

\begin{tabular}{lc}
\hline SF36 Domains & $\overline{\mathrm{x}} \pm E P M$ \\
\hline Functional capacity & $86.47 \pm 1.64 \mathrm{~A}^{* *}$ \\
Physical aspect & $66.06 \pm 3.33 \mathrm{~B}^{* *}$ \\
Pain & $62.23 \pm 2.66 \mathrm{~B}^{* *}$ \\
General health status & $65.59 \pm 2.06 \mathrm{~B}^{* *}$ \\
Vitality & $66.19 \pm 2.17 \mathrm{~B}^{* *}$ \\
Social aspects & $60.72 \pm 2.85 \mathrm{~B}^{* *}$ \\
Emotional aspects & $44.32 \pm 3.99 \mathrm{C}^{* *}$ \\
Mental health & $60.22 \pm 2.25 \mathrm{~B}^{* *}$ \\
\hline "The capital letters (A, B and C) indicate the domains which presented in average &
\end{tabular}

Table 4 -Beck Depression Inventory (BDI) descriptive statistics of the PAS users., CAPS ad. - Mato Grosso, 2011

\begin{tabular}{lcc}
\hline Beck Depression Inventory & $\mathbf{( n = 1 0 9 )}$ & $\mathbf{\%}$ \\
\hline Depression & 41 & 37.6 \\
Dysphoria & 14 & 12.8 \\
Normal & 54 & 49.6 \\
\hline Total & 109 & 100.00 \\
\hline
\end{tabular}

Table 5 - Spearman correlation coefficients between the SF-36 domains and BDI. CAPS ad. - Mato Grosso. 2011

\begin{tabular}{lcc}
\hline Dimension & Beck Depression Inventory $^{*}$ & $\mathbf{p}^{\text {*** }}$ \\
\hline Functional capacity & -0.463 & $<0.001$ \\
Physical aspect & -0.465 & $<0.001$ \\
Pain & -0.446 & $<0.001$ \\
General health status & -0.557 & $<0.001$ \\
Vitality & -0.596 & $<0.001$ \\
Social aspects & -0.541 & $<0.001$ \\
Emotional aspects & -0.301 & 0.001 \\
Mental health & -0.714 & $<0.001$
\end{tabular}

"Spearman correlation coefficient $(\rho)$.

" $p=p$-value associated to the Spearman correlation test $(\rho)$.

\section{DISCUSSION}

The findings of the present study, in relation to the average age of users, are similar to the means obtained in other studies, as well as the high prevalence of PAS among the male users ${ }^{(11,16)}$. The pattern analysis of alcohol and drugs consumption in a representative sample of the Brazilian urban population demonstrated a significant difference in some moment of life in males in relation to females $^{(11)}$. In this context, studies about the prevalence and incidence of PAS use, although the divergences in the consumption patterns within countries, it is common to report males as major consumers ${ }^{(17)}$.

Although there is a social prejudice in relation to any substance dependency, women are still more stigmatized in comparison to men. More aggressive stereotypes are attributed to them, a tendency to promiscuity and failures in following their family role. Besides all changes in social roles of men and women, this stereotype is still present, making the access of those women to treatment difficult. This way, women are generally under-represented in therapeutic centers ${ }^{(18)}$.
In our sample, in relation to marital status, single and divorced people formed a $65.14 \%$ percentage, that is, a big proportion reported as not having a partner or a stable relationship. A study demonstrating the risk factors for drugs consumption, specially the abusive consumption, emphasized that among other variables, marital status was an important aspect to be considered ${ }^{(19)}$, a fact that was re-affirmed in a tobacco dependency and QL investigation, in which, within the social problems, the ones related to partners overcame the others ${ }^{(20)}$.

These findings allow hypothesizing that PAS users have a higher difficulty in keeping a stable marital relationship, in consequence of the behavior triggered by the use, making affective relationships unstable. This situation is grounded as the partners share an environment full of conflicts, threats, disqualification and jealousy, reflecting in distance and hopelessness ${ }^{(21)}$. It is valid to highlight a study with caregivers and chemical dependent individuals, conducted in Mato Grosso State in 2010, aiming to evaluate the burden of care that found most of caregivers as wives, and those presented depression symptoms and lack of sexual interest, which was the most contributing factor to this situation ${ }^{(22)}$, confirming the difficulty to live with this adverse situation.

In accordance with the level of education, there was a predominance of users who only completed basic education. The low level of education within PAS users can be attributed, within other factors, to the lack of motivation and the discontinuity of investment in education, interrupting early education activities. Studies show that low school performance is associated with heavy use of alcohol and other drugs, with possibility to cause neuropsychological alterations with learning loss, causing low performance, leading to low self-esteem and interruption of academic activities ${ }^{(19)}$.

The low level of education, allied with the fact of a third of the study population had referred to have none occupation at the moment of the research, calls attention to the lack of professional qualification and low insertion in the job market, interfering in the perspective of social reinsertion.

In relation to PAS, the inhalants (denominated solvents, as loló, lança-perfume and others) are the most used substances in Brazil. Thus, in the south of the country the marijuana assumes this position ${ }^{(19)}$, an evident fact in this study in which the higher proportion of users referred to marijuana as the most used PAS. A study conducted in Rio de Janeiro-RJ, corroborates with this finding, pointing to marijuana as the most used illicit drug, with a $77.8 \%$ prevalence, followed by crack/cocaine, with $58.6 \%{ }^{(23)}$. The easy access to drugs, as well as the low cost and, still, the fact of marijuana being considered a less aggressive drug and with less social stigma, can contribute to the increase of its use.

A study discussing the extent of damage from the use of marijuana found that within those who experimented 
the substance, an average of $10 \%$ became daily users and 20 to $30 \%$ will consume it weekly ${ }^{(12)}$. Although the cerebral alterations from the use of marijuana are more subtle when compared to other PAS, it does not mean the nonexistence and relevance of it. Therefore, as the consumption can cause damages, within them the mental disorders ${ }^{(12)}$, the subject is particularly important to the mental health team in the planning and implementation of care.

In the present study, the base paste was the second most used PAS during life, appearing in first place for actual use within the users in treatment. The base paste of cocaine (PBC) is common in the Brazilian regions north and mid-west, it is handcraft prepared in improvised laboratories especially to keep its low cost. Many toxic substances are added to it, provoking an adulteration in it with high concentration of those toxic products ${ }^{(24)}$, exposing the users to many diverse organic and psychiatric damages.

It is important to note that users reported the continuity of PAS use during the data collection. This situation can be related to the non-priority of total abstinence as basic premise to the treatment in the service, an actual policy assumed by the CAPS ad, of Damage Reduction. In this perspective, the results are sought in a long term period, the abstinence is a consequence and the attention is focused on the damages caused by drugs and not in the drug itself. In this matter, it is believed to have more incentive to treatment, besides the possibility of an active posture from the user regarding the continuity of the use or not, that is, a self-responsibility during the therapeutic process.

The results related to the first drug used in life allow inferring that in similarity to other investigations, in this study there was a predominance of marijuana. A national research in 2008 pointed that $80.1 \%$ of interviewed people used marijuana in their first time consuming PAS, and from those $79.6 \%$ had it from friends, family members or people they $\mathrm{knew}^{(11)}$. The initial use of any PAS aims to aspects as social acceptance, challenging norms, and desire to feel the substance effect within others. Independently of the motive for its use, it normally starts during adolescence, intensifying the demand for preventive programs for this age group ${ }^{(25)}$ aimed to the reduction of damages from the early use, propitiating better conditions of QL.

The use of PAS and QL have been discussed in its majority in American studies, showing that within PAS users, lower scores of QL when compared to the general population and with other patients with chronic diseases ${ }^{(4,13)}$.

In Brazil, the results are not different. A study from Pelotas-RS verified a significant association between lower scores of QL and the use of alcohol and/or other drugs. In our study population, the QL scores were considerably lower in comparison to QL scores from the general population from this city ${ }^{(26)}$, reinforcing the negative influence of the PAS use in the subjective perception of QL.
Considering the $\mathrm{QL}$ as a subjective outcome, it should be assessed by different domains. In this study, the most compromised domains were the emotional, mental and social aspects. Similar results were obtained in an investigation in Canada, comparing the QL of patients in severe medical conditions and opiates users, especially for the social, emotional aspects, energy and vitality and, still, limitations caused by mental disorders ${ }^{(3)}$.

In the last decade, the occurrence of mental disorders and the PAS use have been largely recognized in the psychiatric clinic, with emphasis for depressive symptoms ${ }^{(27)}$. This way, the evident depressive symptoms in more than one third of the study sample are in accordance with the findings obtained for this population, in which the percentages were $35.0 \%{ }^{(19)}$ and with a variation of 30 to $50.0 \%$, respectively ${ }^{(27)}$.

The depressive symptoms have been the most studied within the psychiatric disorders in relation to quality of life ${ }^{(28)}$, and it was observed in the present study a strong correlation between the depressive symptoms and all QL domains. This correlation results in the $\mathrm{QL}$ decline of users as depression increases the pain sensation and the functional capacity, decreases the quality of the social relationships and makes the adherence to the treatment harder ${ }^{(29)}$.

We observed the domains strongly correlated with depression symptoms were mental health, involving psychic alterations, as well as the feeling of sadness, anxiety and others, and the vitality domain, referred to energy for routine activities, disposition and the relationship with the will to transform decisions in actions. This identification allow the planning of strategies more directed with focus in individual needs, aimed to facilitate the adherence to treatment and recovery, propitiating the restart of activities of body care, leisure, social activities and others.

It is important to emphasize that although the literature shows evidence of the correlation between depression and QL, nowadays, it has been discussed if the $Q L$ concepts and depression are overlapped or distinct ${ }^{(28)}$, due to both being based in a theoretical model of wellbeing, that depression can cause negative influence in the perception of QL and, still, that QL evaluates psychopathological aspects, as depressive symptoms ${ }^{(28,30)}$.

On the other hand, there is evidence that QL of depressed individual are not only associated to the presence of depressive symptoms, but there is also different psychosocial variables, suggesting that depression and QL are correlated concepts, but distinct ${ }^{(30)}$.

Even when facing questions referred to its theme that seem to be still inconclusive, there is a consensus in the literature that the association between depression and quality of life represent an impact in the individual's live, being relevant the comprehension of the applicability of the quality of life concept in health care, as well as the methodological limitations involved in the study of this measure ${ }^{(28)}$. 
The obtained data in the study reaffirm the hypothesis of the presence of depressive symptoms having an important impact in the quality of life. Thus, the assessment of quality of life seem to be a relevant outcome, because its multidimensionality is potentially capable to detect the magnitude and the broadness of compromise that depression imposes ${ }^{(28)}$.

It is important to note that our study design does not allow the establishment of causal relationships. Therefore, longitudinal studies can be done aiming to establish with more clarity the relationship between depression and QL.

The study findings reaffirm the need for efforts within the multi professional team, for the whole evaluation of the user, as well as for the diagnostic elucidation, aiming adequate therapeutic institutions to attend the symptoms and improve the QL.

It is important to highlight that in Brazil, and more specifically in Mato Grosso State, studies of attention services to PAS users using evaluation translated and validated scales are scarce. Therefore, few limitations should

\section{REFERENCES}

1. Jesus CF, Rezende MM. Dirigentes de instituições que assistem dependentes químicos no Vale do Paraíba. Estud Psicol (Campinas). [Internet]. 2008 [citado 2013 ago. 22];25(4):499-507.

2. Moreira TC, Figueiró LR, Fernandes S, Justo DM, Dias IR, Barros HMT, et al. Quality of life of users of psychoactive substances, relatives, and non-users assessed using the WHOQOLBREF. Ciên Saúde Coletiva [Internet]. 2013 [cited 2014 Jan 12];18(7):1953-62. Available from: http://www.scielo.br/pdf/ csc/v18n7/10.pdf

3. Millson PE, Challacombe L, Villeneuve PJ, Fischer B, Strike $\mathrm{CJ}$, Myers T, et al. Self-perceived health among Canadian opiate users: a comparison to the general population and to other chronic disease populations. Can J Public Health. 2004;95(2):99-103.

4. Costenbader EC, Zule WA, Coomes CM. The impact of illicit drug use and harmful drinking on quality of life among injection drug users at high risk for hepatitis $\mathrm{C}$ infection. Drug Alcohol Depend. 2007;89(2-3):251-58.

5. Blay SL, Marchesoni MSM. Association among physical, psychiatric and socioeconomic conditions and WHOQOL-Bref scores. Cad Saúde Pública. 2011;27(4):677-86.

6. Ciconelli RM, Ferraz MB, Santos W, Meinão I, Quaresma MR. Tradução para a língua portuguesa e validação do questionário genérico de avaliação da qualidade de vida SF-36 (Brasil SF36). Rev Bras Reumatol. 1999;39(3):143-50. be considered, as the bibliographic search which showed a reduced number of studies conducted with this instrument, for this population, and within the few found studies, a major part of them were international, making the comparison with our population difficult as they are from another reality. For this reason, we searched for studies with PAS users with other methodologies, aiming to obtain a parameter to analyze the data.

\section{CONCLUSION}

We found scores indicating the QL concerning of PAS users, as well as a strong correlation with depression symptoms. These data contribute with the direction of nursing and multi professional interventions, showing the need to recognize earlier depression symptoms that compromise therapeutic effectiveness, which makes the adherence to treatment difficult and affect negatively the $\mathrm{QL}$ of users. The recognition of those symptoms, as well as its correlation with $\mathrm{QL}$, makes possible the implementation of actions directed to individual and collective needs, consequently, an improvement in QL.

7. Fleck MPA, Leal OF, Louzada S, Xavier M, Chachamovich $E$, Vieira $G$, et al. Desenvolvimento da versão em português do instrumento de avaliação de qualidade de vida da OMS (WHOQOL-100). Rev Bras Psiquiatr. 1999;21(1):19-28.

8. Neves EB, Krueger E, Pietrovski EF, Teixeira ACM, Araujo MR, Scheeren EM. Perfil das publicações sobre qualidade de vida no SciELO. Rev Uniandrade. 2011;12(2):147-61.

9. Scheffer M, Pasa GG, Almeida RMM. Dependência de álcool, cocaína e crack e transtornos psiquiátricos. Psicol Teoria Pesq. 2010;26(3):533-41.

10. Facundo FRG, Pedrão LJ. Personal and interpersonal risk factors in the consumption of illicit drugs by marginal adolescents and young people from juvenile gang. Rev Latino Am Enferm. 2008;16(3):368-74.

11. Bastos FI, Bertoni N, Hacker MA. Drug and alcohol use: main findings of a national survey, Brazil 2005. Rev Saúde Pública 2008;42 Supl 1:109-17.

12. Jungerman FS, Lararanjeira R, Bressan RA. Maconha: qual a amplitude de seus prejuízos? Rev Bras Psiquiatr. $2005 ; 27(1): 5-6$.

13. Dalgard O, Egeland A, Skaug K, Vilimas K, Steen T. Healthrelated quality of life in active injecting drug users with and without chronic hepatitis $\mathrm{C}$ virus infection. Hepatology. 2004;39(1):74-80. 
14. Cordeiro LRO, Oliveira MS, Souza RC. The scientific production of Psychosocial Care Centers. Rev Esc Enferm USP [Internet]. 2012 [cited 2014 Jan 22];46(1):119-23. Available from: http://www.scielo.br/pdf/reeusp/v46n1/ en_v46n1a16.pdf

15. Gorestein C, Andrade L. Inventário de depressão de Beck: propriedades psicométricas da versão em português. Rev Psiquiatr Clín (São Paulo). 1998;25(5):245-50.

16. Leal EM, Godinho DPG, Mann R, Strike C, Brands B, Khenti A. Estudo de comorbidade: sofrimento psíquico e abuso de drogas em pessoas em centros de tratamento, Macaé Brasil. Texto Contexto Enferm. 2012;21(n.esp):96-104.

17. Sousa FSP, Oliveira EN. Caracterização das internações de dependentes químicos em Unidade de Internação Psiquiátrica de Hospital Geral. Ciênc Saúde Coletiva. 2010;15(3):671-7.

18. Hochgraf PB, Brasiliano S. Mulheres e substâncias psicoativas. In: Seibel SD, organizador. Dependência de drogas. 2a edição. São Paulo: Atheneu; 2010. p.1025-42.

19. Medina MG, Santos DN, Almeida Filho NM, Barqueiro CC. Epidemiologia do consumo de substâncias psicoativas. In: Seibel SD, organizador. Dependência de drogas. 2a edição. São Paulo: Atheneu; 2010. p.71-98.

20. Portugal FB, Correa APM, Siqueira MM. Alcoolismo e comorbidade em um programa de assistência aos dependentes de álcool. SMAD Rev Eletr Saúde Mental Álcool Drog [Internet]. 2010 [citado 2014 jan. 17];6(1):113. Disponível em: http://pepsic.bvsalud.org/pdf/smad/ v6n1/06.pdf

21. Santos ECV, Martin E. Cuidadoras de pacientes alcoolistas no município de Santos, SP, Brasil. Rev Bras Enferm. 2009;6(2):194-99.

22. Marcon SR, Rubira EA, Espinosa MM, Barbosa DA. Quality of life and depressive symptoms among caregivers and drug dependent people. Rev Latino Am Enferm. 2012;20(1):167-74.
23. Vargens $\mathrm{OMC}$, Brands B. Use of illicit drugs and critical perspectives of drug users' relatives and acquaintances in Northern Rio de Janeiro (City), Brazil. Rev Latino Am Enferm. 2009;17(n.spe):776-82.

24. Seibel SD. Cocaína e crack. In: Seibel SD, organizador. Dependência de drogas. 2a edição. São Paulo: Atheneu; 2010. p. 217-30.

25. Gabatz RIB, Schmidt AL, Terra MG, Padoin SMM, Silva AA, Lacchini AJB. Percepção dos usuários de crack em relação ao uso e tratamento. Rev Gaúcha Enferm. 2013;34(1):140-6.

26. Jansen K, Mondin TC, Ores LC, Souza LD, Konradt $\mathrm{CE}$, Pinheiro RT, et al. Mental common disorders and quality of life in young adulthoods: a population-based sample in Pelotas, Rio Grande do Sul State, Brazil. Cad Saúde Pública. 2011;27(3):440-8.

27. Zaleski M, Laranjeira RR, Marques ACPR, Ratto L, Romano $\mathrm{M}$, Alves HNP, et al. Diretrizes da Associação Brasileira de Estudos do Álcool e outras Drogas (ABEAD) para o diagnóstico e tratamento de comorbidades psiquiátricas e dependência de álcool e outras substâncias. Rev Bras Psiquiatr. 2006;28(2):142-8.

28. Lima AFBS, Fleck MPA. Qualidade de vida e depressão: uma revisão da literatura. Rev Psiquiatr Rio Gd Sul [Internet]. 2009 [citado em 25 de abril de 2014];31(3 Supl). Disponível em: http://www.scielo.br/pdf/rprs/v31n3s0/v31n3a02s1.pdf

29. Couto ER, Couto E, Vian B, Gregório Z, Nomura ML, Zaccaria $R$, et al. Quality of life, depression and anxiety among pregnant women with previous adverse pregnancy outcomes. São Paulo Med J. 2009;127(4):185-9.

30. Aigner $M$, Forster-Streffleur $S$, Prause $W$, Freidl $M$, Weiss $M$, Bach $M$. What does the WHOQOL-Bref measure? Measurement overlap between quality of life and depressive symptomatology in chronic somatoform pain disorder. Soc Psychiatry Psychiatr Epidemiol. 2006;41(1):81-6. 